Bangladesh J. Plant Taxon. 20(2): 207-211, 2013 (December)

(C) 2013 Bangladesh Association of Plant Taxonomists

\title{
NEW LICHEN RECORDS FROM TURKEY
}

\author{
KenAn YaZiCI ${ }^{1}$, Ali Aslan ${ }^{2}$ AND André Aptroot ${ }^{3}$ \\ Biology Department, Faculty of Science, Karadeniz Technical University, \\ 61080, Trabzon, Turkey
}

Keywords: Ascomycota; Lichen; Burdur; Turkey.

\begin{abstract}
Three lichen species, namely Cladonia grayi G. Merr. ex Sandst., Pertusaria subventosa Malme var. subventosa, and Parmelia squarrosa Hale are reported as new to Turkey as a result of a lichenological survey in the Burdur region of the country. Descriptions are presented, including geographic distribution, substrate, chemistry, and comparisons with morphologically similar taxa.
\end{abstract}

\section{Introduction}

Although many lichen taxa have recently been recorded for Turkey (Aptroot and Yazici, 2009, 2012; Arslan et al., 2011; Candan and Halıc1, 2011; Karagöz et al., 2011; Karagöz and Aslan, 2012; Kınalığlu and Aptroot, 2011; Osyczka et al., 2011; Vondrák et al., 2012; Yazıc1 et al., 2010a, b, c), the lichen biota of Turkey is still incompletely known, as is in many parts of the world. Therefore, more studies are needed to achieve a complete lichen flora of Turkey.

Burdur in Turkey has a continental Mediterranean climate with cold, snowy winters and very hot, long and dry summers. The mean annual temperature is $15^{\circ} \mathrm{C}$ and the temperature ranges from $-16^{\circ} \mathrm{C}$ to $39^{\circ} \mathrm{C}$. The mean annual rainfall is about $468 \mathrm{~mm}$ and the average humidity is $51.2 \%$ (Akman, 1999). Only 25 lichenized fungi have thus far been reported for this region (Çobanoğlu, 2005; Öztürk et al., 2005; Pišút and Guttová, 2008; Şenkardeşler, 2009).

The visited areas, Bucak, and Altnnyayla districts, are mountainous with much forest dominated by Abies, Cedrus, Ficus, Fraxinus, Juniperus, Olea, Pinus, Pistacia, Prunus, Quercus (especially Altınyayla district), Rhus species and alternating streams, lakes, dams (e.g. Yapraklı Dam in Altınyayla district and Karacaören dam in Bucak district) (Baytop and Denizci, 1963). The underforest flora is very abundant in these areas where the bedrock consists mainly of marble.

This paper presents first reports of lichenological exploration in the region of Burdur, southwestern Turkey.

\section{Materials and Methods}

Lichen samples were collected on 28 - 29 June 2012, air-dried and examined with a Nikon SMZ1500 stereomicroscope and a Nikon Eclipse 80i compound light microscope. For the identifications relevant keys were consulted (Archer and Elix, 1993; Brodo et al., 2001; Goward, 1999; Messuti et al., 2007; Smith et al., 2009). Thin Layer Chromatography (TLC) analyses were carrried out when needed for Cladonia grayi and Pertusaria subventosa var. subventosa (Orange et al., 2001). Vouchers are stored in the Herbarium of the Biology Department, Karadeniz Technical University, Trabzon, Turkey (KTUB). The descriptions are based on Turkish specimens and completed with data from the indicated literatures (Archer and Elix, 1993; Brodo et al., 2001; Dobson, 2005; Duncan, 1970; Goward, 1999; Hale, 1973; Hyvönen, 1985; Wirth, 1995).

${ }^{1}$ Corresponding author. Email: kcagri_1997@yahoo.com

${ }^{2}$ Biology Department, Kazım Karabekir Education Faculty, Atatürk University, Erzurum, Turkey.

${ }^{3}$ ABL Herbarium G.v.d. Veenstraat 107, NL-3762 XK Soest, The Netherlands. 


\section{Results}

Cladonia grayi G. Merr. ex Sandst., Sandstede: Clad. Exs. no.: 1847 (1929).

(Fig. 1).

Primary tallus squamulose, shrub-like, mostly curved upwards; upper surface corticate, \pm green; rhizines and isidia absent, soralia \pm present; upper surface verruculose, minutely wartedsquamulose; podetia pale, 1.0-1.5(-1.7) $\mathrm{mm}$ high, not blackening; proliferations present and arising strictly from cup margins; podetial squamules few; the cup margins pinkish, rim \pm even, not pointed-crownlike; apothecia brown to dark brown; hymenial ascoma 1.0-2.0 mm, stalked; ascospores oblong, with obtuse tips $9-12 \times 2-3(-4) \mu \mathrm{m}$, without septa, hyaline, colourless; perispore and epispore absent; conidia falcate; fumarprotocetraric acid and grayanic acid present; photobiont Asterochloris. Primary thallus $\mathrm{C}-, \mathrm{K}-, \mathrm{KC}-, \mathrm{P} \pm$ red, medulla $\mathrm{P}-$ or yellow, UV+ iceblue. [Some morphological and chemical characters taken from Goward (1999)].

Habitat: Cladonia grayi is a holarctic species, found on soil rich in humus, more rarely on conifer wood, peat, dead leaves, turf, rotting wood, mosses over mineral soil.

Distribution: Costa Rica, North America, Japan, Spain, Italy, Russia, Germany, the Netherlands, Norway, Estonia, Finland, New Zealand and USA. New to Turkey.

Specimen examined: Turkey. Burdur: Altınyayla, between İbecik-Altınyayla, main roadside, $36^{\circ} 58^{\prime} 07.19^{\prime \prime N} / 29^{\circ} 26^{\prime} 17.70^{\prime \prime E}, 1348 \mathrm{~m}$, on soil, 29.06.2012, K.Yazici (KTUB 2340).

Notes: Cladonia grayi is similar to C. chlorophaea (Flörke ex Sommerf.) Spreng., and Cladonia merochlorophaea Asahina but $C$. grayi has podetia with few detachable microsquamules on the lower half, while these occur abundantly in C. merochlorophaea. The presence of fumarprotocetraric acid together with grayanic acid in C. grayi helps to distinguish it from $C$. chlorophaea with the exclusive presence of fumarprotocetraric acid (Goward, 1999; Smith et al., 2009). Accompanying species: Cladonia humilis.

Parmelia squarrosa Hale, Phytologia 22(1): 29 (1971).

(Fig. 2a,b).

Thallus foliose, adnate or \pm adnate on its substrata, whitish-grey, greenish or greenish-grey; lobes divaricate, contiguous or imbricate, $0.7-2.5 \mathrm{~mm}$ wide. Upper surface plane or foveolate with laminal and marginal pseudocyphellae forming a reticulate network; isidia present, fine and cylindrical, up to $0.5 \mathrm{~mm}$ tall and becoming more concentrated in older central areas of the thallus and marginal parts of the lobes. Rhizines squarrose, but mostly simple at the margins of lobe. Apothecia absent. Cortex $\mathrm{K}+$ yellow, medulla $\mathrm{K}+$ yellow turning red, $\mathrm{C}-, \mathrm{P}+$ orange. [Some morphological characters taken from Hale (1971)].

Habitat: Parmelia squarrosa commonly grows as epiphyte on deciduous and coniferous trees near the coast and rarely on rock and decayed wood.

Distribution: Mostly found in oceanic areas in temperate and boreal regions. Distributed in America, Asia (Japan, China, Korea, Nepal, Russia), Canada and Europe (the Alps of western Austria and southern Switzerland). This species is new to Turkey.

Specimen examined: Turkey, Burdur: Bucak, between Beşkonak-Kocaaliler, $3 \mathrm{~km}$ to

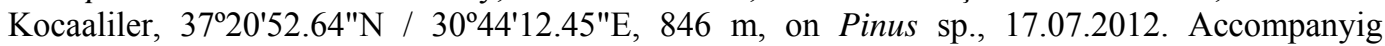
species: Lepraria sp., Parmelia sulcata, P. saxatilis and P. tiliacea, K.Yazici (KTUB-2339).

Notes: Parmelia squarrosa is similar to $P$. saxatilis but $P$. squarrosa has squarrosely branched rhizines at least in part, while they are always simple or sometimes furcately dichotomously branched in $P$. saxatilis. The upper cortex in $P$. squarrosa is whitish, greenish or greenish-grey while $P$. saxatilis has a shiny, bluish-grey or brownish-grey upper cortex, which is often browning at the tips of lobe (Hale, 1973). The lobes in P. saxatilis are more branched and 
broader (3-4 $\mathrm{mm})$ than those of $P$. squarrosa $(0.7-2.0 \mathrm{~mm})$. The isidia in $P$. squarrosa are mostly on marginal parts of the lobes than those of $P$. saxatilis.
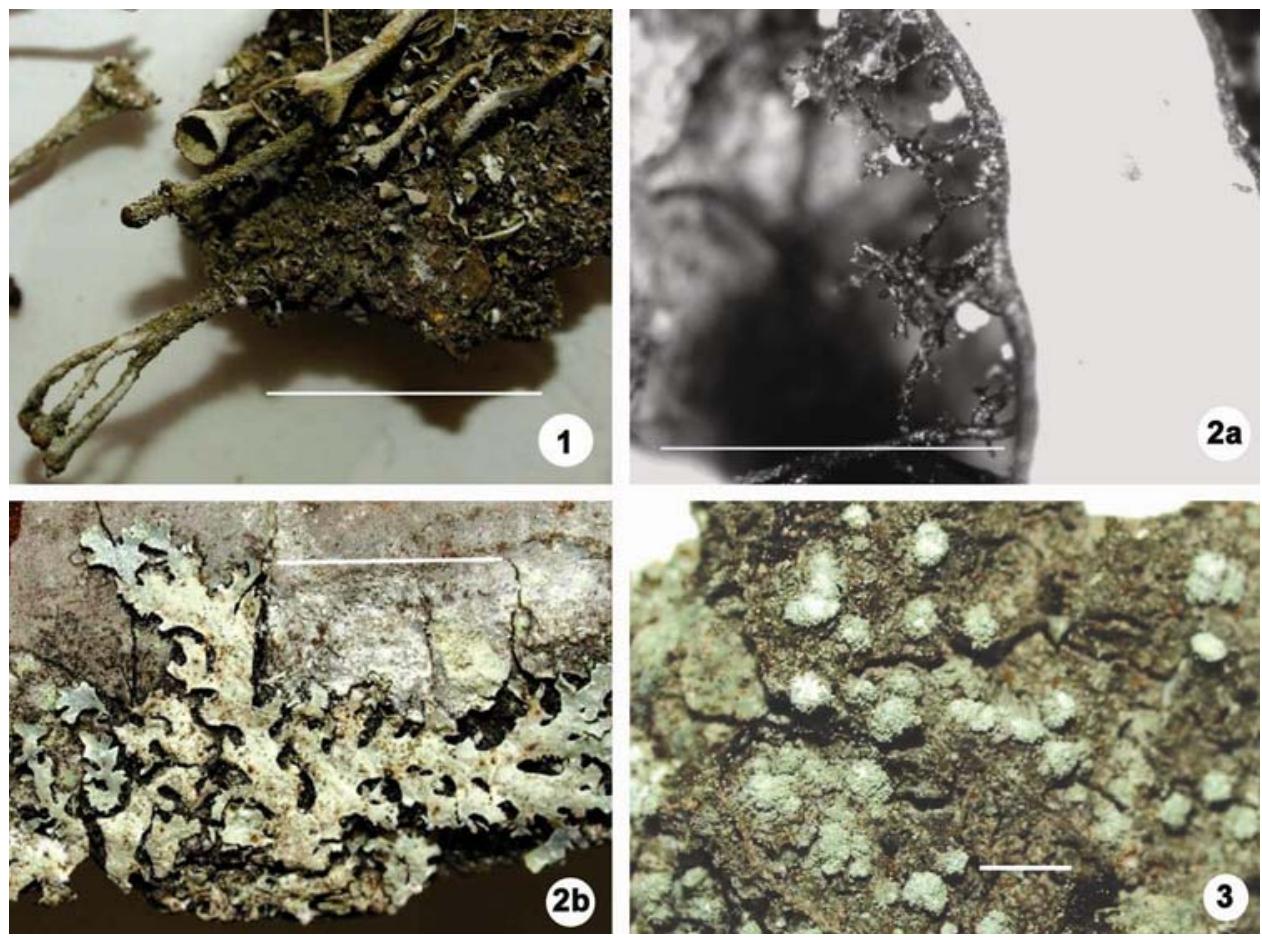

Figs 1-3: 1. Cladonia grayi (cups bottom), Cladonia humilis (cups above), habitus (Scale $=1 \mathrm{~cm}$ ). 2 a. Parmelia squarrosa (with squarrosely branched rhizines), habitus (Scale $=1 \mathrm{~mm}$ ). 2b. Parmelia squarrosa (upper surface of thallus), habitus (Scale $=1 \mathrm{~cm})$. 3. Pertusaria subventosa var. subventosa, habitus $($ Scale $=1 \mathrm{~mm})$

Pertusaria subventosa Malme var. subventosa, Ark. Bot. 28A (no. 9): 7 (1936).

(Fig. 3).

Thallus crustose, up to $6 \mathrm{~cm}$ in diameter, white to greyish-white or dark drey, thick, cracked and areolate, smooth. Soralia present, \pm conspicuous, white, numerous, $0.5-1.8(-2.0) \mathrm{mm}$ in diameter, scattered or confluent away from the margin, subglobose, occasionally slightly stipitate. Apothecia absent. Soralia $\mathrm{K}+$ yellow, $\mathrm{KC}+$ violet, $\mathrm{C}-$, $\mathrm{P}+$ yellow, $\mathrm{UV}+$ bright yellow, containing lichexanthone (major), thamnolic acid (major) and picrolichenic acid (major), rarely with additional norstictic acid. [Some morphological and chemical characters taken from Archer and Elix (1993)].

Habitat: Pertusaria subventosa var. subventosa is a holarctic species, growing mostly on calcareous rocks.

Distribution: Australia, Brazil, China and New Zealand. New to Turkey.

Specimen examined: Turkey, Burdur: Altınyayla, between İbecik-Altınyayla, main roadside, $36^{\circ} 58^{\prime} 07.19^{\prime \prime} \mathrm{N} / 29^{\circ} 26^{\prime} 17.70 " \mathrm{E}, 1348 \mathrm{~m}$, on soil and calcareous rock, 29.06.2012, K.Yazici (KTUB 2338). 
Notes: Pertusaria subventosa has morphologically identical three varieties distinguished by the $\mathrm{K}$ - reaction of the soralia. The $\mathrm{K}+$ yellow reaction of the soralia caused by the presence of thamnolic acid in P. subventosa var. subventosa differentiates it from the other two varieties lacking this substance on them. Accompanying species: Lepraria cf. lobificans.

\section{Acknowledgements}

This study was supported by TUBITAK (Project 111T857).

\section{References}

Akman, Y. 1999. İklim ve Biyoiklim (Biyoiklim Metodları ve Türkiye İklimleri). 1. Baskı, Kariyer Matbaacılık Ltd. Şti., Ankara. pp. 350.

Aptroot, A. and Yazıc1, K. 2009. Opegrapha pauciexcipulata, a new corticolous lichen from Turkey. Mycotaxon 108: 155-158.

Aptroot, A. and Yazıc1, K. 2012. A new Placopyrenium (Verrucariaceae) from Turkey. Lichenologist 44: 739-741.

Archer, A.W. and Elix, J.A. 1993. Additional new taxa and a new report of Pertusaria (lichenized Ascomycotina) from Australia. Mycotaxon 49: 143-150.

Arslan, B., Öztürk, S. and Oran, S. 2011. Lecanora, Phaeophyscia and Rinodina species new to Turkey. Mycotaxon 116: 49-52.

Baytop, A. and Denizci, R. 1963. Türkiye'nin Flora ve Vejetasyonuna Genel Bakış. Ege Üniversitesi Matbaas1, İzmir. pp. 43.

Brodo, I.M., Sharnoff, S.D. and Sharnoff, S. 2001. Lichens of North America. New Haven, Conn. Yale University Press, London. pp.795.

Candan, M. and Halıc1, M.G. 2011. New Cercidospora records for Turkey. Turkish J. Bot. 35: 625-629.

Çobanoğlu, G. 2005. Lichen collection in the herbarium of Univ. Istanbul (ISTF). Turkish J. Bot. 29: 69-74

Dobson, F.S. 2005. Lichens. An illustrated guide to the British and Irish species. The Richmond Publishing Co.Ltd., Slough. pp. 480.

Duncan, U.K. 1970. Introduction to British Lichens. Arbroath: T.Buncle \& Co. Ltd., Printers and Publishers. Market Place. pp. 292.

Goward, T. 1999. The lichens of British Columbia Illustrated Keys Part 2 - Fruticose species. Special Report Series 9. Ministry of Forests Research Program. British Columbia. pp. 319.

Hale, M.E. 1971. Parmelia squarrosa, a new species in section Parmelia. Phytologia 22: 29.

Hale, M.E. 1973. Fine structure of the cortex in the lichen family Parmeliaceae viewed with the scanningelectron microscope. Smithson. Contr. Hot. 10: 1-13.

Hyvönen, S. 1985. Parmelia squarrosa, a lichen new to Europe. Lichenologist 17(3): 311-314.

Hue, A.M. 1899. Lichenes extra-europaei (Suite). Nouv. Arch. Mus. Hist. Nat. Paris 4: 27-220.

Karagöz, Y., Aslan, A., Yazıc1, K. and Aptroot, A. 2011. Diplotomma, Lecanora, and Xanthoria lichen species new to Turkey. Mycotaxon 115: 115-119.

Karagöz, Y. and Aslan, A. 2012. Floristic lichen records from Kemaliye district (Erzincan) and Van Province. Turkish J. Bot. 36: 558-565.

Kınalığlu, K. and Aptroot, A. 2011. Carbonea, Gregorella, Porpidia, Protomicarea, Rinodina, Solenopsora, and Thelenella lichen species new to Turkey. Mycotaxon 115: 125-129.

Messuti, M.I., Becker, U. and Archer, A.W. 2007. New or interesting saxicolous Pertusaria species (Pertusariales: Pertusariaceae) from Zimbabwe. Lichenologist 39: 227-230.

Orange, A., James, P.W. and White, F.J. 2001. Microchemical methods for the identification of lichens. The British Lichen Society, London. pp.101.

Osyczka, P., Yazıcı, K. and Aslan, A. 2011. Note on Cladonia species (Lichenized Ascomycota) from Ardahan Province (Turkey). Acta Societatis Botanicorum Poloniae 80: 59-62. 
Öztürk, S.., Güvenç, Ş. and Aydın, S. 2005. Floristik lichen records from Isparta and Burdur Provinces. Turkish J. Bot. 29: 243-250.

Pišút, I. and Guttová, A. 2008. Contribution to the lichen flora of Anatolia, Turkey. Sauteria 15: 403-415.

Smith, C.W., Aptroot, A., Coppins, B.J., Fletcher, A., Gilbert, O.L., James, P.W., Wolseley, P.A. and Orange, A. 2009. The lichens of Great Britain and Ireland. The British Lichen Society, London. pp.1046 Şenkardeşler, A. 2009. Lichens from Turkey collected by Vašák. Acta Botanica Hungarica 51: 427-436.

Vondrák, J., Halıc1, M.G., Kocakaya, M. and Ondrakova, O.V. 2012. Teloschistaceae (lichenized Ascomycetes) in Turkey. 1. Some records from Turkey. Nova Hedwigia 94: 385-396.

Wirth, V. 1995. Die Flechten Baden-Württembergs. Teil 1-2. Ulmer, Stuttgart.

Yazıcı, K., Aptroot, A., Aslan, A., Etayo, J., Spier, L. and Karagöz, Y. 2010a. Lichenized and lichenicolous fungi from nine different areas in Turkey. Mycotaxon 111: 113-116.

Yazıc1, K., Aptroot, A. and Aslan, A. 2010b. Three lichenized fungi new to Turkey and the Middle East. Mycotaxon 111: 127-130.

Yazıc1, K., Elix, J.A. and Aslan, A. 2010c. Some parmelioid lichens new to Turkey and Asia. Mycotaxon 111: $489-494$. 